\title{
Effect of Abiotic Stress on Irrigated Maize Forage Yield as Compared to Sorghum
}

\author{
S.H. Mohammed ${ }^{1, a}$ and M.I. Mohammed ${ }^{2, b^{*}}$ \\ ${ }^{1}$ Forage \& Range Research Program, Soba Research Station, Khartoum, Sudan \\ ${ }^{2}$ Forage Improvement Program, Agricultural Research Corporation (ARC), Khartoum North, Sudan \\ asawsanhassbo@gmail.com, bmaaroufibrahim@gmail.com
}

Keywords: Salt stress, water stress, heat stress, maize vs sorghum.

\begin{abstract}
A study was conducted in Sudan (Africa) during the summer and winter seasons (2013 2014) at two locations: Shambat (normal soils) and Soba (salt-affected soils). Nine maize (Zea mays L.) and sorghum (Sorghum bicolor (L.) Moench) cultivars were studied under two watering regimes arranged in split plot experiment in a randomized complete block design. The eight test-environments created by the combination of locations, seasons and watering regimes were used to investigate the effect of salt, water and heat stresses on forage yield and some related traits. The results showed that separate and combined stress factors significantly reduced forage yield. The greatest reduction in dry matter yield caused by one factor was shown by salt stress $(29.6 \%)$ and the least reduction was caused by heat stress $(3.9 \%)$. Water stress coupled with either heat or salt stress caused the greater reduction in yield (37.0\%-43.3\%) than the combination of the other factors. Full stress caused $53.8 \%$ yield reduction. Days to tasseling was significantly reduced by heat stress whereas water and salt stress showed no significant effect on tasseling duration. Full stress caused the greatest effect on days to tasseling. Plant height and stem diameter were significantly reduced by salt and water stress. Two hybrids kept top rank in yield through most abiotic stress levels showing resilience to unfavourable environments. All maize genotypes significantly outyielded the sorghum check under no heat stress (winter sowing) regardless of the effect of salt and water stresses while the opposite is true under the heat stress (summer sowing). It was concluded that salt and water stress are the major abiotic stresses limiting forage maize production. Maize tolerates have been better reduction in temperature than does sorghum while the latter tolerate better salt and water stresses than does maize. Forage maize could be competitively grown during summer if water and salt stresses are avoided.
\end{abstract}

\section{Introduction}

Maize (Zea mays L.) forage has become a major constituent of ruminant rations in recent years. It is the only crop amongst non-leguminous fodders that combines better nutritional quality along with a high quantity of biomass [1,2]. Although the crop has wide adaptability [3] it is the least tolerant to abiotic stresses among cereals. Drought, salinity and elevated temperatures, are among the major abiotic stresses that negatively impact maize production in most maize production regions worldwide [4-7]. Salt stressed soils occur in all continents and under almost all climatic conditions. Their distribution, however, is relatively more extensive in the arid and semi-arid regions compared to the humid regions [8]. Interactions between water, salt and heat stress have a significant negative effect on maize performance. Currently, $50 \%$ of all irrigated schemes are affected by salinity. The increasing frequency of dry spells in many regions of the world and the problems associated with salinity in irrigated areas frequently result in the wide occurrence of drought and salinity on cultivated land [9]. Such abiotic stresses are prevailing in Sudan and should be seriously considered when introducing or developing new maize cultivars. The total salt-affected soils in Sudan are 4.8 million hectares, of which 2.1 million hectares are saline and 2.7 million hectares are sodic soils [10]. Thus, sorghum, which tolerates harsh conditions better than maize, has become the major forage crop. In Sudan, where the second largest animal herd in Africa exists, there is a need for continuing supply of fodder throughout the year, a situation which can't be met by sorghum alone specially during winter where maize is supposed to have a competitive stand against sorghum as a forage crop [11]. A 
common consensus among forage growers is that maize is the best option to replace sorghum in winter sowings. If fed as green fodder, maize is sought to have a good reputation to increase milk production [12].

The objectives of this study were to: Investigate the effects of the major abiotic stress factors on the performance of maize as forage crop; validate the advantage of replacing maize with sorghum for forage production in the winter season and identify maize hybrids showing resilience to abiotic stress.

\section{Materials and Methods}

The study was conducted in Sudan (Khartoum State) during 2013-2014 at two different locations: Shambat (Lat. 15 39' N; Long. 32 ${ }^{\circ} 31^{\prime}$ E; Alt 380 masl) and Soba (Lat. $15^{\circ} 24^{\prime}$ N; Long. $32^{\circ}$ 32 ' E; Alt 380 masl). Soba is located about $25 \mathrm{~km}$ south of Shambat. In each location, the trial was carried out in the Experimental Farm of the Agricultural Research Corporation (ARC).

\section{The plant material}

Ten genotypes comprising 9 maize varieties plus one forage sorghum cultivar included as a check were used in the study (Table 1).

Table 1. Plant material used in the study

\begin{tabular}{llll}
\hline S.N. & Genotype & Type/Color & Source \\
\hline 1 & PAN-6966 & Yellow maize hybrid & South Africa \\
2 & PAN-12 & Yellow maize hybrid & South Africa \\
3 & PAN-14 & Yellow maize hybrid & South Africa \\
4 & PAN-6P110 & Yellow maize hybrid & South Africa \\
5 & Hytech1100 & White maize Hybrid & Egypt \\
6 & Hytech2066 & Yellow maize hybrid & Egypt \\
7 & Hytech2031 & White maize hybrid & Egypt \\
8 & Hytech2055 & Yellow maize hybrid & Egypt \\
9 & Hudieba2 & Yellow maize (open pollinated $)$ & Sudan \\
10 & Kambal & Sorghum(open pollinated) & Sudan \\
\hline
\end{tabular}

\section{Test-environments}

The stress levels comprised 2 locations (normal soils at Shambat vs salty soil at Soba), 2 seasons (summer vs winter) and 2 watering intervals ( 1 vs 2 weeks). The combination of these levels ( $2 \times 2 \times 2)$ gives eight test-environments assumed to create different normal vs abiotic stress levels (Table 2) used to test the performance of the above genotypes.

Table 2. Abiotic stress levels created by different environment combinations.

\begin{tabular}{lllll}
\hline & & \multicolumn{2}{l}{ Environment combination (growing conditions) } \\
\hline S.N. & Abiotic stress levels & location & Season & Water \\
\hline 1 & No stress & Shambat & Winter & Normal \\
2 & Water stress & Shambat & Winter & Stressed \\
3 & Heat stress & Shambat & Summer & Normal \\
4 & Water + Heat stress & Shambat & Summer & Stressed \\
5 & Salt stress & Soba & Winter & Normal \\
6 & Water + Salt stress & Soba & Winter & Stressed \\
7 & Salt + Heat stress & Soba & Summer & Normal \\
8 & Full stress & Soba & Summer & Stressed \\
\hline
\end{tabular}


The soils at Shambat are well drained loamy clay, non-saline and non-sodic with $\mathrm{pH}$ ranging 7.7 - 7.9 (Appendix I). The soil at Soba is hazarded by salinity (ECe $=12-14 \mathrm{dS} / \mathrm{m}$ ) and sodicity $(\mathrm{ESP}=24-27),(\mathrm{SAR}=16-23)$ (Appendix II), with high clay content, low infiltration and permeability, low organic matter and nitrogen and high $\mathrm{pH}$ (Appendix III). The monthly mean temperatures of the growing seasons are presented in Appendices IV and V. The average min-max temperature during the winter season (Nov. -Feb.) ranged $15-20^{\circ} \mathrm{C}$ and $32-38^{\circ} \mathrm{C}$ whereas that at summer (April-July) ranged $25.0-28.4^{\circ} \mathrm{C}$ and $36.9-42.0^{\circ} \mathrm{C}$. The weather is dry in both growing seasons especially during Winter.

\section{The experimental design and cultural practices}

To achieve the above treatment combinations 4 trials were conducted 2 at each location (Shambat and Soba) in each season (winter and summer). Each trial was split plot experiment with watering regimes assigned to the main plots and the genotypes to the subplots in a randomized complete block design (RCBD) with three replications. Unless otherwise indicated, the cultural practices followed were the same in the 4 trials. The land was disc ploughed, disc harrowed and levelled by scraper to obtain fine seed bed. Ridging was done at $0.75 \mathrm{~m}$ spacing. The plot consisted of four ridges $4 \mathrm{~m}$ long. Two seeds were placed in holes spaced at $15 \mathrm{~cm}$ on one side of the ridge. The winter sowing was done on the $8^{\text {th }}$ and $12^{\text {th }}$ of Dec. 2013 in Soba and Shambat, respectively. The summer sowings were done on the $13^{\text {th }}$ and $19^{\text {th }}$ of May 2014 in Soba and Shambat, respectively. Nitrogen fertilizer $(55 \mathrm{kgN} / \mathrm{ha})$ was applied in a form of urea at the second watering. Weed population was kept to the minimum by hand weeding.

\section{Data collection}

Forage yield was estimated at dough stage by harvesting the two inner rows of each plot leaving $0.5 \mathrm{~m}$ from each side of the ridge. The plants were cut at the ground level and weighed in the field immediately after cutting using spring balance. A random sample of $1.0 \mathrm{~kg}$ taken from each harvested plot was air dried to a constant weight and used to convert the fresh weight of the corresponding plot to the dry matter yield (DMY). Days to $50 \%$ tasselling, plant height, stem diameter and plant count at harvest were recorded.

\section{Statistical analysis}

The data collected were subjected to the standard procedure of analyzing split plot in RCB design [13]. The combined analysis of variance of the genotypes across the 8-test environments (stress levels) was performed using the Genstat statistical packages [14].

\section{Results}

Table 3 shows mean squares from genotype, environment (stress levels) and their interaction obtained for forage yield and related traits. The analysis of variance revealed highly significant differences among genotypes, environments and their interaction for all studied traits.

Table 3. Mean squares from genotype, environment (stress levels) and their interaction obtained for forage yield and some related traits of 10 genotypes

\begin{tabular}{llllll}
\hline Source of variation & DF & \multicolumn{3}{c}{ Mean Squares } \\
\hline & & $\begin{array}{l}\text { Days to } \\
\text { tasseling }\end{array}$ & $\begin{array}{l}\text { Plant height } \\
(\mathrm{cm})\end{array}$ & $\begin{array}{l}\text { Stem diameter } \\
(\mathrm{cm})\end{array}$ & $\begin{array}{l}\text { Dry matter } \\
\text { yield (tha) }\end{array}$ \\
Block & 2 & 17.93 & 33.304 & 0.005663 & 1.2476 \\
Environments $(\mathrm{E})$ & 7 & $1379.91^{* *}$ & $20470.294^{* *}$ & $0.328407^{* *}$ & $165.0029 * *$ \\
Residual & 14 & 17.43 & 14.692 & 0.000856 & 0.6311 \\
Genotypes $(\mathrm{G})$ & 9 & $207.27 * *$ & $2896.960^{* *}$ & $0.851612^{* *}$ & $34.8476^{* *}$ \\
G×E & 63 & $48.47^{* *}$ & $1181.065^{* *}$ & $0.036378^{* *}$ & $19.5506^{* *}$ \\
Residual & 144 & 17.50 & 7.421 & 0.001029 & 0.4517 \\
\hline
\end{tabular}

** = Highly significant at 0.01 probability level 


\section{Effect of abiotic stress levels}

Table 4 shows the effect of different stress levels on forage yield and some related traits. The DMY recorded under full stress was $5.78 \mathrm{t} / \mathrm{ha}$. The lowest DMY for single stress level was recorded by salt stress $(8.94 \mathrm{t} / \mathrm{ha})$ with a reduction in yield amounting to $29.6 \%$. Heat stress alone gave the least effect on DMY (12.2 t/ha) with yield reduction amounting to 03.9\%. Water stress coupled with either salt or heat stress has a greater effect on yield than the combination of the other stress levels with a respective reduction in DMY amounting to $43.3 \%$ and $37.0 \%$.

Heat stress caused a significant reduction in days to tasseling $(-16.6 \%)$ compared to no stress whereas water and salt stress have no significant effect with a respective change in tasseling duration of $-1.62 \%$ and $+0.67 \%$. The greatest reduction was shown by full stress $(-20.2 \%)$. Unlike days to tasseling, plant height was significantly reduced by salt stress $(-15.7 \%)$ and water stress $(-13.1 \%)$ with heat stress showed the least reduction $(-5.05 \%)$. The effect of stress factors on stem diameter followed the same trend as in plant height.

Table 4. Effect of different stress levels on forage yield and related traits at dough stage (Shambat, Soba 2013-2014)

\begin{tabular}{|l|l|l|l|l|l|l|l|l|}
\hline & $\begin{array}{l}\text { Days } \\
\text { to } \\
\text { tasseli } \\
\text { ng }\end{array}$ & $\begin{array}{l}\text { Change } \\
(\%)\end{array}$ & $\begin{array}{l}\text { Plant } \\
\text { height } \\
(\mathrm{cm})\end{array}$ & $\begin{array}{l}\text { Change } \\
(\%)\end{array}$ & $\begin{array}{l}\text { Stem } \\
\text { diameter } \\
(\mathrm{cm})\end{array}$ & $\begin{array}{l}\text { Change } \\
(\%))\end{array}$ & DMY & $\begin{array}{l}\text { Change } \\
(\%)\end{array}$ \\
\hline Heat stress & 62.1 & -16.6 & 188 & -5.05 & 1.59 & +6.71 & 12.2 & -03.9 \\
\hline Water stress & 73.1 & -1.62 & 172 & -13.1 & 1.39 & -6.71 & 10.1 & -20.5 \\
\hline Salt stress & 74.8 & +0.67 & 167 & -15.7 & 1.38 & -7.38 & 8.94 & -29.6 \\
\hline $\begin{array}{l}\text { Water + Heat } \\
\text { stress }\end{array}$ & 60.7 & -18.3 & 159 & -19.7 & 1.43 & -4.03 & 8.00 & -37.0 \\
\hline Salt + Heat stress & 61.4 & -17.4 & 137 & -30.8 & 1.37 & -8.05 & 8.92 & -29.8 \\
\hline $\begin{array}{l}\text { Water + Salt } \\
\text { stress }\end{array}$ & 71.0 & -4.44 & 149 & -24.7 & 1.35 & -9.40 & 7.20 & -43.3 \\
\hline Full stress $\dagger$ & 59.3 & -20.2 & 119 & -39.9 & 1.23 & -17.4 & 5.87 & -53.8 \\
\hline No stress $\dagger$ & 74.3 & - & 198 & - & 1.49 & - & 12.7 & - \\
\hline Mean & 67.1 & & 161 & & 1.40 & & 9.23 & \\
\hline SE \pm & 0.762 & & 0.70 & & 0.00534 & & 0.1450 & \\
\hline LSD (5\%) & 2.312 & 6.2 & & 1.12 & 0.01620 & & 0.4399 & \\
\hline CV (\%) & 6 & & 2.3 & & 7.3 & \\
\hline
\end{tabular}

$\dagger:$ The compound effect of water + heat + salt stresses

$\$$ : No water, heat or salt stresses

\section{Performance of genotypes across stress levels:}

Table 5 shows the mean performance of genotypes in different stress levels for DMY. All of the maize genotypes recorded their lowest values in forage yield under full stress with the lowest DMY (3.51 t/ha) shown by PAN14 and the highest one (7.52 t/ha) exhibited by Hytech2031. On the other hand, the best performance in DMY was shown under no stress (15.9 t/ha) recorded for PAN12. Among maize genotypes, the highest reduction in yield resulting from full stress as compared to no stress was shown by Hytech1100 (75.3\%), and PAN14 (73.2 \%) whereas the lowest reduction was shown by Hytech2031 (48.1\%). The genotypes Hytech2031, Hytech2055 and PAN12 that showed the best DMY under full stress were also the best yielders under no stress. These genotypes were also the best performing under single stress levels and combinations of two stress levels as well. The sorghum check Kambal significantly outyielded the maize genotypes in stress levels including heat stress (summer growing) whereas the opposite is true for stress levels not including heat stress (winter growing) with DMY ranging from 3.81 under salt + water stress to $20.2 \mathrm{t} / \mathrm{ha}$ under heat stress. 
Table 5. Performance of genotypes in different stress levels for dry matter yield (t/ha) (Shambat, Soba 2013-2014).

\begin{tabular}{|c|c|c|c|c|c|c|c|c|c|}
\hline \multirow[b]{2}{*}{ Genotypes } & \multicolumn{9}{|c|}{ Stress levels } \\
\hline & $\begin{array}{l}\text { Heat } \\
\text { Stress }\end{array}$ & $\begin{array}{l}\text { Water } \\
\text { Stress }\end{array}$ & $\begin{array}{l}\text { Salt* } \\
\text { stress }\end{array}$ & $\begin{array}{l}\text { Water + } \\
\text { Heat } \\
\text { stress }\end{array}$ & $\begin{array}{l}\text { Salt + } \\
\text { Heat } \\
\text { stress }\end{array}$ & $\begin{array}{l}\text { Water + } \\
\text { Salt } \\
\text { stress }\end{array}$ & $\begin{array}{l}\text { Full } \\
\text { stress }\end{array}$ & $\begin{array}{l}\text { No } \\
\text { stress }\end{array}$ & $\begin{array}{l}\% \\
\text { Reduction } \\
\text { in yield } \\
\text { (full } \\
\text { stress vs } \\
\text { no stress) }\end{array}$ \\
\hline PAN6966 & 10.0 & 9.87 & 9.48 & 7.02 & 6.17 & 7.49 & 4.02 & 14.4 & 72.1 \\
\hline PAN12 & 13.0 & 11.7 & 10.7 & 8.45 & 9.09 & 8.50 & 6.12 & 15.9 & 61.5 \\
\hline PAN14 & 9.47 & 9.05 & 7.20 & 5.68 & 6.90 & 5.66 & 3.51 & 13.1 & 73.2 \\
\hline PAN6P-110 & 9.82 & 10.2 & 7.33 & 7.94 & 6.65 & 8.23 & 5.51 & 11.8 & 53.3 \\
\hline Hytech1100 & 10.9 & 10.6 & 10.5 & 4.32 & 6.22 & 7.23 & 2.96 & 12.0 & 75.3 \\
\hline Hytech2066 & 11.2 & 10.8 & 11.6 & 7.73 & 7.57 & 7.83 & 4.95 & 13.5 & 63.3 \\
\hline Hytech2031 & 12.7 & 11.9 & 10.3 & 9.05 & 11.9 & 7.80 & 7.52 & 14.5 & 48.1 \\
\hline Hytech2055 & 13.8 & 11.7 & 10.4 & 8.64 & 9.56 & 8.59 & 5.94 & 14.5 & 59.0 \\
\hline Hudeiba2 & 10.6 & 10.0 & 8.02 & 6.64 & 7.62 & 6.81 & 4.88 & 10.7 & 54.4 \\
\hline Kambal $\dagger$ & 20.2 & 4.82 & 3.84 & 14.5 & 17.6 & 3.81 & 13.3 & 6.58 & +102 \\
\hline Mean & & & & & 9.23 & & & & \\
\hline SE \pm & & & & & 0.395 & & & & \\
\hline LSD (5\%) & & & & & 1.105 & & & & \\
\hline CV (\%) & & & & & 7.3 & & & & \\
\hline
\end{tabular}

*: Salinity / Sodicity stress

$\dagger$ : Sorghum check

\section{Contrast analysis for maize vs sorghum}

Table 6 shows the mean squares from contrast analysis of maize vs sorghum over eight environments for forage yield. Analysis of variance revealed highly significant differences between maize genotypes (as a group) and sorghum represented by the check Kambal. Differences among environments and the interaction of contrast (maize vs sorghum) with the environment were also highly significant for forage yield.

Table 7 shows the contrast performance of maize vs sorghum for dry matter yield over eight environments. The DMY of maize ranged between 5.05 and $13.4 \mathrm{t} / \mathrm{ha}$ under full and non-stress, respectively, while that of sorghum for the respective stress levels ranged from 13.3 to $6.58 \mathrm{t} / \mathrm{ha}$ which represent growing sorghum during summer and winter, respectively. Differences between maize and sorghum in forage yield were highly significant. In winter sowings, maize excels sorghum in forage yield regardless of water and/or salt stresses and vice versa for summer sowings. 
Table 6. Mean squares from contrast analysis of maize vs sorghum over eight environments (Shambat and Soba .2013-2014)

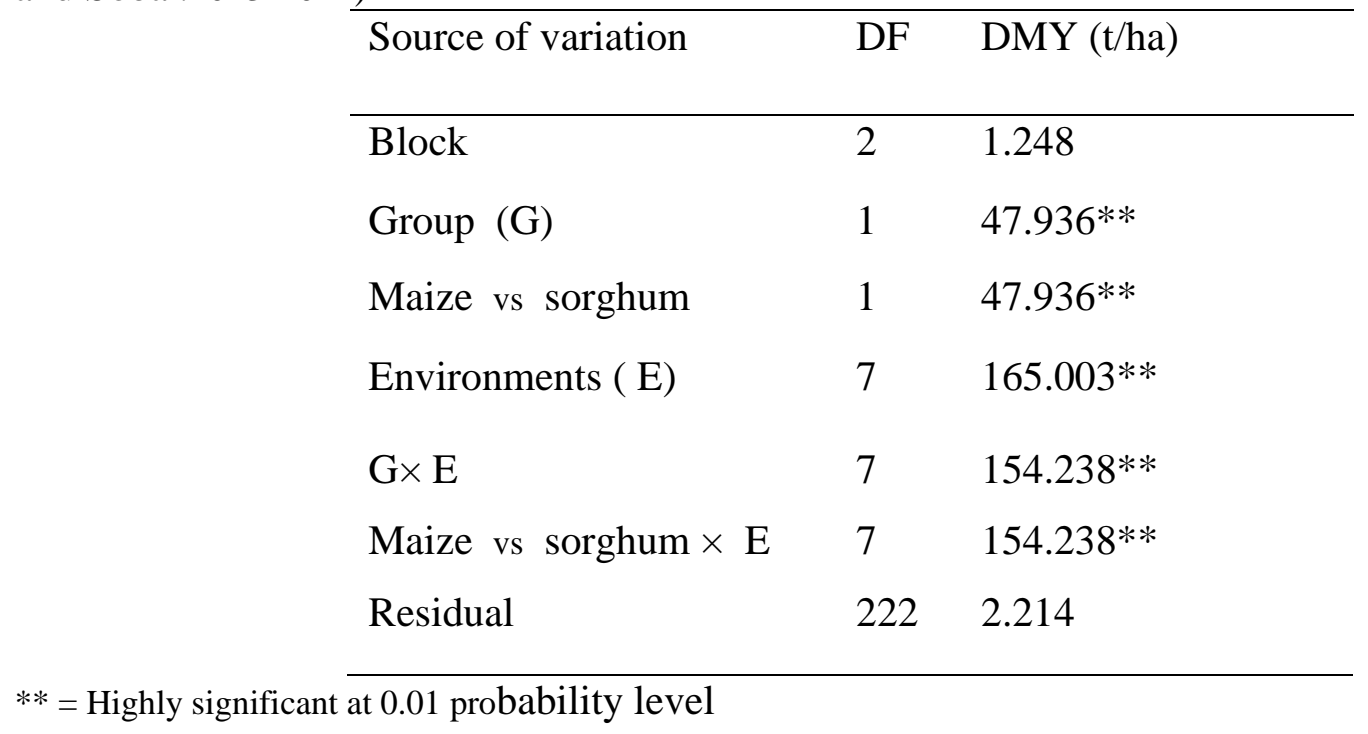

Table 7. Contrast performance of maize vs sorghum for dry matter yield ( $t /$ ha) over eight stress environments (Shambat and Soba .2013-2014)

\begin{tabular}{|c|c|c|c|c|c|c|c|c|}
\hline \multirow[b]{2}{*}{ Group } & \multicolumn{8}{|c|}{ Environments } \\
\hline & $\begin{array}{l}\text { Heat } \\
\text { Stress }\end{array}$ & $\begin{array}{l}\text { Water } \\
\text { Stress }\end{array}$ & $\begin{array}{l}\text { Salt } \\
\text { stress }\end{array}$ & $\begin{array}{l}\text { Water + } \\
\text { Heat } \\
\text { stress }\end{array}$ & $\begin{array}{l}\text { Salt + } \\
\text { Heat } \\
\text { stress }\end{array}$ & $\begin{array}{l}\text { Water + } \\
\text { Salt } \\
\text { stress }\end{array}$ & $\begin{array}{l}\text { Full } \\
\text { stress }\end{array}$ & $\begin{array}{l}\text { No } \\
\text { stress }\end{array}$ \\
\hline Maize & 11.3 & 10.6 & 9.51 & 7.28 & 7.96 & 7.57 & 5.05 & 13.4 \\
\hline Sorghum & 20.2 & 4.82 & 3.84 & 14.5 & 17.6 & 3.81 & 13.3 & 6.58 \\
\hline Maize vs Sorghum & \multicolumn{8}{|c|}{$* *$} \\
\hline Mean & \multicolumn{8}{|c|}{9.2} \\
\hline $\mathrm{SE} \pm$ & \multicolumn{8}{|c|}{0.8591} \\
\hline $\mathrm{CV}(\%)$ & \multicolumn{8}{|c|}{16.1} \\
\hline
\end{tabular}

\section{Discussions}

The highly significant differences among the eight environments for forage yield (Table 3) validate the effectiveness of such designed environments in testing the performance of genotypes for abiotic stress. The highly significant GxE interaction indicates that the performance of genotypes in forage yield across the eight environments (stress levels) was inconsistently implying the need for performing stability analysis to investigate the contribution of each genotype in the observed GxE interaction.

The study showed that each of the separate stress levels caused a significant reduction in forage yield; however, salt stress irrespective of other stress factors caused the greatest yield reduction $(29.6 \%)$. Salt stress is one of the most significant abiotic factors limiting crop productivity [15]. According to FAO reports [16] 50\% yield reduction in maize occurred due to salt stress at $\mathrm{ECe}=5$ $9 \mathrm{dS} / \mathrm{m}$. In this study, salt stress is represented by the inherently saline-sodic soils of Soba with EC ranging from 8 - $15 \mathrm{dS} / \mathrm{m}$ and ESP ranging from 30 to 50 . The compound effect of salinity and sodicity seriously affect maize growth [17] with forage attributes being more affected than grain ones [18].

The study showed that water stress has the second largest adverse effect on maize with a reduction in forage yield amounting to $20.5 \%$. The adverse effect of water stress on maize has been reported by many workers $[19,20]$. In a study with the similar watering interval, extending the watering interval from 7 to 14 days gave a reduction in maize yield of about $37 \%$ [21]. Other studies showed the advantageous effect of shortening watering interval on maize growth has been reported by some workers [22, 23]. 
The study showed that heat stress gave the least reduction in forage yield compared to the reduction caused by salinity and water stresses. This goes well with the fact that maize is originally a tropical crop with the ability to tolerate relatively high temperature [24]. Moreover, its grain yield rather than forage yield that is more affected by heat stress. Reduction in forage yield attributes occurs at temperatures higher than $40{ }^{\circ} \mathrm{C}$ [25-28] whereas, that of grain yield occurs at a lower threshold $\left(32.5^{\circ} \mathrm{C}\right)$ when coinciding with pollination $[29,30]$.

The study revealed that any combination of two stress factors resulted in a reduction in forage yield greater than that of a single factor with full stress (all factors) causing the greatest effect. However, the compound effect of water stress with either salt or heat stress caused a greater reduction in forage yield than that caused by heat with salinity stress. This agrees with the findings reported by Heiniger [31] for the interaction of water stress with each of salt and heat stresses.

The maize hybrids Hytech2031, PAN12 and Hytech2055 appeared to be the best forage yielders under a wider range of environments. PAN12 showed the best green matter yield (GMY) and may have good potential for forage production under green chopping system. Hytech2031 and Hytech2055 have been reported by Mohammed [32] to show good performance in grain and forage production, therefore, may be suggested for both green chop and silage making systems. Owing to their good performance under salt affected environments, the three hybrids in addition to Hytech2066 may be notified for forage production in Soba area or similar environments.

The contrast analysis confirmed further that maize excels sorghum in forage yield when sown during winter season irrespective of water and salt stresses while the opposite is true for summer sowings. Such results indicate that maize tolerates showed a better reduction in temperature than does sorghum while the latter tolerate better the effect of salt and water stresses than dose maize. This substantiates the previous finding [33] however, as revealed by the analysis of variance (Table 6) the interaction of maize vs sorghum $x$ environment was highly significant pointing to the inconsistency of such comparison across the environment.

\section{Conclusions}

Salt and water stress are the major abiotic stresses limiting forage maize production. Heat stresses have the least effect on the yield of forage maize. Maize tolerates showed a better reduction in temperature than does sorghum while the latter tolerate better salt and water stresses than does maize. However, the potential of maize tolerance to salt stress exists as evident from the performance of the hybrid Hytech2031. Forage maize could be competitively grown during summer if water and salt stresses are avoided. Future research should consider traits pertaining to forage maize for silage production.

\section{Conflict of Interest}

The authors declare that there is no conflict of interest.

Appendix I. Chemical and physical soil properties of the experimental site at Shambat

\begin{tabular}{llllllll}
\hline Depth & \multicolumn{3}{c}{ Chemical properties } & \multicolumn{3}{c}{ Physical properties } \\
\hline$(\mathrm{cm})$ & $\mathrm{pH}$ & $\begin{array}{l}\mathrm{EC}(\mathrm{dS} \\
\left.\mathrm{m}^{-1}\right)\end{array}$ & $\begin{array}{l}\mathrm{Na} \\
\left(\mathrm{mmol} \mathrm{L}^{-1}\right)\end{array}$ & SAR & $\begin{array}{l}\text { Clay } \\
(\%)\end{array}$ & $\begin{array}{l}\text { Silt } \\
(\%)\end{array}$ & $\begin{array}{l}\text { Sand } \\
(\%)\end{array}$ \\
\hline $0-15$ & 7.79 & 1.4 & 5.1 & 2.4 & 42.1 & 15.9 & 42.0 \\
$15-35$ & 7.88 & 1.0 & 4.3 & 2.5 & 39.6 & 15.8 & 44.6 \\
$35-51$ & 7.87 & 1.2 & 7.1 & 4.5 & 44.1 & 16.4 & 39.5 \\
$51-75$ & 7.91 & 2.0 & 12.5 & 6.3 & 51.4 & 16.6 & 32.0 \\
$75-120$ & 7.71 & 2.2 & 16.0 & 9.2 & 50.0 & 16.6 & 33.4 \\
\hline
\end{tabular}


Appendix II. Chemical soil properties of the experimental site at Soba

\begin{tabular}{llllll}
\hline Depth & $\mathrm{pH}$ paste & $\mathrm{pH} 1: 5$ & $\mathrm{EC} \mathrm{dS} \mathrm{m}^{-1}$ & SAR & ESP \\
\hline $0-30$ & 8.1 & 8.8 & 14.0 & 23.0 & 27.0 \\
$30-60$ & 8.3 & 8.9 & 12.0 & 16.0 & 24.0 \\
\hline
\end{tabular}

Soluble Cations and Anions Saturation Extract $\left(\mathrm{meq} \mathrm{L}^{-1}\right)$

\begin{tabular}{lllllll}
\hline & $\mathrm{Na}$ & $\mathrm{Ca}$ & $\mathrm{Mg}$ & $\mathrm{Cl}$ & $\mathrm{CaCo} 3$ & $\mathrm{HCo} 3$ \\
\hline $0-30$ & 10.3 & 32.5 & 6.0 & 8.3 & 0.0 & 4.6 \\
$30-60$ & 19.0 & 32.5 & 6.5 & 6.3 & 0.0 & 4.3 \\
\hline
\end{tabular}

Exchangeable Bases (meq $\left.100 \mathrm{~g}^{-1}\right)$

\begin{tabular}{lllllll}
\hline & $\mathrm{Na}$ & $\mathrm{K}$ & $\mathrm{CEC}$ & $\mathrm{N}(\%)$ & $\mathrm{C} / \mathrm{N}(\%)$ & Available P (ppm) \\
\hline $0-30$ & 10.94 & 0.94 & 40 & 0.421 & 0.037 & 5.0 \\
$30-60$ & 6.83 & 1.04 & 28 & 0.468 & 0.042 & 3.8 \\
\hline
\end{tabular}

Source: Soil survey and land evacuation report. Land and Water Research Centre. ARC. Wad Medani. Sudan.

Appendix III. Physical soil properties of the experimental site at Soba

Depth (cm) Mechanical analysis Soil moisture $\quad \mathrm{H}_{2} \mathrm{O}$ in soil $\mathrm{H}_{2} \mathrm{O}$ in horizon

\begin{tabular}{lllllllllll}
\hline & Cs & Fs & Si & C & $1 / 2$ bar & 15 bar & AWC & Vol\% & Cm/cm & \\
\hline $0-20$ & 8 & 18 & 37 & 37 & 27.2 & 13.6 & 13.6 & 22.0 & 0.33 & 6.6 \\
$20-50$ & 4 & 30 & 21 & 45 & 28.9 & 15.5 & 13.4 & 21.8 & 0.22 & 6.6 \\
$50-80$ & 7 & 17 & 33 & 43 & 28.5 & 15.3 & 13.2 & 22.8 & 0.23 & 6.9 \\
$80-120$ & 4 & 23 & 33 & 40 & 27.1 & 14.6 & 12.5 & 20.8 & 0.21 & 8.4 \\
$120-160$ & 5 & 20 & 29 & 46 & 36.1 & 19.0 & 17.1 & 30.4 & 0.30 & 12.0 \\
\hline
\end{tabular}

Source: Soil survey and land evacuation report. Land and Water Research Centre. ARC. Wad Medani. Sudan.

Appendix IV. Monthly mean temperature $\left({ }^{\circ} \mathrm{C}\right)$, rainfall and relative humidity $(\mathrm{R} . \mathrm{H} \%)$ during the winter season $(2013 / 2014)$.

\begin{tabular}{lllll}
\hline \multirow{2}{*}{ Month } & \multicolumn{2}{l}{$\begin{array}{l}\text { Mean } \\
\text { Temperature }\end{array}$} & R.H. $(\%)$ & Total rain fall (mm) \\
\cline { 2 - 3 } & Max. & Min. & & \\
\hline November 2013 & 34.0 & 20.0 & 27 & 0.0 \\
December & 32.0 & 16.0 & 32 & 0.0 \\
January 2014 & 32.0 & 15.0 & 35 & 0.0 \\
February & 33.0 & 16.0 & 27 & 0.0 \\
March & 38.0 & 20.0 & 23 & 0.0 \\
\hline
\end{tabular}

Source: Meteorological Authority, Ministry of environment Forestry and Physical Development (2014) Khartoum. Sudan.

Appendix V. Monthly mean temperature $\left({ }^{\circ} \mathrm{C}\right)$, rainfall and relative humidity (R.H \%) during the summer season (2014).

\begin{tabular}{lllll}
\hline \multirow{2}{*}{ Month } & \multicolumn{2}{l}{ Mean temperature } & \multirow{2}{*}{ R.H. (\%) } & Total rain fall $(\mathrm{mm})$ \\
\cline { 2 - 3 } & Max. & Min. & & \\
\hline April & 40.9 & 27.4 & 16 & Trace \\
May & 41.0 & 28.4 & 17 & 4.6 \\
June & 42.0 & 25.0 & 21 & 0.6 \\
July & 36.9 & 26.1 & 45 & 73.6 \\
\hline
\end{tabular}

Source: Meteorological Authority, Ministry of environment Forestry and Physical Development (2014) Khartoum. Sudan. 


\section{References}

[1] L.J. Anil, R.H. Phipps, The potential of forage-maize intercrops in ruminant nutrition, Animal Feed Science and Technology. 85 (2000) 157-164.

[2] J.A. Cusicanqui, J.G. Lauer, Plant density and hybrid influence on corn forage yield and quality, Agro. J. 91 (1999) 911-915.

[3] M. Koutsika- Sotiriou, Hybrid seed production in maize, in: A.S. Basra (Ed.), Heterosis and hybrid seed production in agronomic crops, Food Products Press, NewYork, 1999, pp. 25-64.

[4] M. Cooper et al., Breeding drought-tolerant maize hybrids for the US corn-belt: Discovery to product, J. Exp. Bot. (2014). doi: 10.1093/jxb/eru064.

[5] I. Ahuja, R.C. de Vos A.M. Bones, Plant molecular stress responses face climate change, Trends Plant Sci. 15 (2010) 664-674.

[6] R. Ngara, R. Ndimba J.B. Jensen, Identification and profiling of salinity stress-responsive proteins in Sorghum bicolor seedlings, J. Proteomics. 75 (2012) 4139-4150.

[7] W. Schlenker, M.J. Roberts, Nonlinear temperature effects indicate severe damages to U.S. crop yields under climate change, Proc. Nat. Acad. Sci. USA. 106 (2009) 15594-15598.

[8] J.D. Oster, R. C. Reeve M. Fireman, Salt problems in relation to irrigation, In: Irrigation of agricultural lands (ed. by R. M. Hagen), Agronomy J. 11 (1967) 988-1008.

[9] K. H. Amer, Corn crop response under managing different irrigation and salinity levels, Agric. Water Manage. 97 (2010)1553-1563.

[10] FAO, The use of saline waters for crop production - FAO irrigation and drainage paper 48, Available: http://www.fao.org/docrep/t0667e/t0667e00.HTM. (2000).

[11] A.B. Elahmadi, A.B. Elahmadi, A proposal for the release of two maize hybrids for the irrigated central clays of Sudan, A paper submitted to the Variety Release Committee, Khartoum, Sudan. (2012) 1-12.

[12] A.E. Kambal, Comparative performance of some varieties of sorghum, maize and pearl millet for forage production, Sudan Agricultural Journal. 10 (1984) 46-60.

[13] W.G. Cochran, G.M. Cox, Experimental designs, $2^{\text {nd }}$ edn. John Wiley and Sons, Inc. New York. (1957) 293-316.

[14] Genstat, Ninth edition. Version - 9.1.0.174.Lawes Agricultural Trust (Rothamsted Experimental Station) VSN International, Hertfordshire (2011).

[15] B. Bojović et al., Effects of $\mathrm{NaCl}$ on seed germination in some species from families Brassicaceae and Solanaceae, Kragujevac Journal of Science. 32 (2010) 83-87.

[16] FAO, FAOSTAT, Food and Agricultural Organization of the United National http://www.feedipedia.org/node/5351. (2011).

[17] I.S. Afzal et al., Improving germination and seedling vigour in wheat by haloprimingunder saline conditions, Pakistan Journal of Agricultural Sciences. 44 (2007) 40- 49.

[18] R. Munns, Comparative physiology of salt and water stress, Plant Cell Environ. 25 (2002) 239-250.

[19] J.O. Payero et al., Effect of timing of a deficit-irrigation allocation on corn evapotranspiration, yield, water use efficiency and dry mass, Agricultural Water Management. 96 (2009) 13871397.

[20] M.B. Khan, H.A. Nazim, I.B. Muammad, Effect of water stress on growth and yield component of maize varieties, Research science. 12 (2001) 15-18. 
[21] FAO, Crop water requirements under arid condition, Dallyn. P.M, more food from better technology, Rome. (1983) 383-392.

[22] H.E. Elawad, Growth and Production of Maize (Zea mays L.) as Affected by Water Treatment, Organic and Inorganic Fertilizers M. Sc. Thesis, Faculty of Agric. U. of K., Sudan. (2007).

[23] M.A. Ibrahiem et al., Proceedings of the Meetings of the National Crop Husbandry Committee $39^{\text {th }}$, Agricultural Research Corporation, Wad Medani, Sudan. (2005) 105-125.

[24] M. Ashraf, M. Hafeez, Thermo tolerance of pearl millet and maize at early growth stages: growth and nutrient relations, Biol. Plant. 48 (2004) 81-86.

[25] R.S. Dubey, Photosynthesis in plants under stressful conditions, in: M. Pessarakli (Ed.), Handbook of Photosynthesis, 2nd edition, CRC press, Boca Roton, Florida, 2005, pp. 717-737.

[26] S. H. Kim et al., Temperature dependence of growth, development and photosynthesis in maize under elevated CO2, Environ. Exp. Bot. 61 (2007) 224-236.

[27] A. Wahid et al., Heat tolerance in plants: An overview, Environ. Exp. Bot. 61 (2007) 199-223.

[28] Z. Ristic et al., Rubisco activase and wheat productivity under heat stress conditions, J. Exp. Bot. 60 (2009) 4003-404.

[29] T. Hussain et al., Breeding potential for high temperature tolerance in corn (Zea mays L.), Pakistan J. Bot. 38 (2006) 1185-1195.

[30] K. L. Smith, Ohio Agron. Guide, Corn prod. Ohio state Univ. USA, bulletin: 472, Steel, R. G. D., Torrie J. H., Deekey. D. A., 1997. Principles and procedures of Statistics, A Biometrical Approach, 3rd ED. Mc Graw Hill Book, Int. Co. New York. (1996) 400-428.

[31] R.W. Heiniger, The impact of early drought on corn yield. Raleigh, NC: North Carolina State University. (2001) Available: http://www.ces.ncsu.edu/plymouth/cropsci/docs/early_drought_impact_on_corn.html.

[32] M. I. Mohammed et al., A proposal for the release of two Egyptian maize hybrids for the irrigated sector in Northern and Central Sudan, A paper submitted to the Variety Release Committee, Khartoum, Sudan. (2013) 1-16.

[33] E.V. Maas, G.J. Hoffman, Crop salt tolerance - current assessment, Journal of the Irrigation and Drainage. 103 ( 1977) 115-134. 